\title{
PROBLEMA
}

Anuario de Filosofia

\section{A COMMON LAW THEORY OF JUDICIAL REVIEW}

\author{
W. J. WALUCHOW
}

\section{Resumen:}

Las cartas constitucionales o declaraciones de derechos han sido aplaudidas por la protección que brindan a las minorias y su función de asegurar derechos fundamentales; sin embargo, también han sido criticadas por ser consideradas moral y politicamente refutables. El autor responde a las objeciones más serias de los críticos y ofrece algunas razones para adoptar un marco alternativo, de acuerdo al cual, las cartas no aspiran a establecer puntos de acuerdo y compromisos previos.

\section{Abstract:}

Constitutional Charters or Bill of Rights have been applauded because of the protection they provide to minorities and also in ensuring and protecting fundamental rights, however, Charters have been criticized for being considered morally and politically objectionable. The author responds to Charter critics most serious objections and offers some reasons for adopting an alternative framework. 
Summary: I. Charters and the Circumstances of Politics. II. The Critics' Case. III. The Living Tree and the Common Law Conception. IV. Some of the Advantages.

\section{Charters and the Circumstances of Politics}

Constitutional Charters or Bills of Rights are usually heralded as good things to have. ${ }^{1}$ They are generally applauded for the protections they are said to provide minorities and for their help in securing fundamental liberal democratic rights. But Charters are not without their detractors. Some Critics argue both that Charters cannot do the work their proponents claim they can, and that they are morally and politically objectionable. In this paper, I would like to respond to a few of the Critics' most serious objections by challenging the very conception of Charters and their aspirations they -and those who believe that Charters are good things to have, a group we'll call "the Advocates" - 2 seem to assume. The assumption shared by Critics and Advocates is that a Charter purports to provide a stable, fixed point of agreement on and pre-commitment to appropriate moral limits to government power. The Advocates argue that such a stable fixed point is not only possible, they contend that it is morally and politically desirable as well. The Critics, as noted above, challenge both these claims. For example, they argue that the agreement and pre-commitment typically presupposed by Advocates cannot exist within what Jeremy Waldron aptly calls "the circumstances of politic". These consist in the "felt need among the members of [plu-

1 In what follows, I will refer only to Charters, with the understanding that everything I say about them applies equally to any other written, constitutional instrument (e.g., the American Bill of Rights) that recognizes fundamental rights of political morality.

2 Henceforth, I will refer to these individuals as "the Advocates," with the understanding that this class of individuals includes a range of authors whose arguments for Charters are not all the same. Advocates within the philosophical literature include Dworkin, Rawls and Samuel Freeman. Those, like Waldron, who argue against practices of judicial review under Charters will be called "the Critics", with the same understanding applying to them. 
ralistic societies] for a common framework or decision or course of action on some matter, even in the face of disagreement about what that framework, decision or action should be". 3 This disagreement extends to the question whether to adopt a Charter, what rights to include within it, and how these rights are to be interpreted and applied. According to Waldron, "it looks as though it is disagreement all the way down, so far as constitutional choice is concerned". 4 Yet if the people in pluralistic societies cannot agree on the content of the moral limits enshrined in their Charters, they cannot intelligibly pre-commit to the stable, fixed point of constitutional limits within which government power is supposed to be exercised on their behalf. And if they cannot pre-commit, then none of the other heralded benefits of Charter protection are possible either - and we therefore have no reason to adopt one.

If this shared picture of Charters is accepted, then I believe it's pretty much game over and the Critics can be declared the winners. So instead of tackling their arguments within the framework established by the shared assumption, I'd like to offer some reasons for adopting an alternative framework according to which Charters do not - or at least need not- aspire to establish fixed points of agreement and pre-commitment; and importantly, they need not presuppose an unwarranted level of confidence in the rectitude of our judgments about moral rights. Rather, they represent a mixture of only very modest agreement and pre-commitment combined with a considerable measure of caution and humility. Far from being based on the dubious assumption that constitutional authors have right answers to the controversial issues of political morality which will arise under a Charter - answers which they are justified in enshrining and imposing on us - my alternative stems from the precise opposite: from recognition that they - and we- do not have

3 Waldron, Jeremy, Law and Disagreement, Oxford, Oxford University Press, 102.

4 Ibidem, 295. 
all the answers to the relevant questions of political morality, and that we do well to design our political and legal institutions in ways which are sensitive to this feature of our predicament. Once we view Charters in this very different light -once, that is, we adopt a kind of Copernican revolution in our thinking about them- we can begin to appreciate more fully not only why Charters might be good things to have, we can see our way clear to answering the Critics' most powerful arguments.

\section{THE CRITICS' CASE}

\section{The Argument from Democracy}

One of the most popular arguments against Charters is that they are inconsistent with the fundamental tenets of democracy. Charters limit the choices open to legislative bodies in significant ways and these limits are usually enforced by unelected, and hence unaccountable, judges. But such an arrangement only serves to thwart the will of the people as expressed through their elected representatives. It is not enough to reply that "the people" have themselves chosen to impose these judicially enforced, entrenched limits on their democratic power, because quite often those limits were set many years ago, raising a very difficult question: Why should "the people now" be restricted in their current choices by what "the people then" might have decided were appropriate limits to entrench in a constitutionespecially given the bias against change which amending formulas typically build into constitutions? This seems clearly inconsistent with the notion of ongoing self-government which lies as the very heart of democratic ideals. Instead of being slaves to a king or despot, we are now slaves to previous generations, and to the unelected judges we ask to decide fundamental questions of political morality for us. According to the Critics, a judicially enforced Charter represents an unflattering, indeed insulting, 
admission that we, the people now, are better off relying on earlier generations, in concert with a small band of judicial elites, to make our decisions of political morality for us. This is an admission, the Critic contends, we really should try to avoid.

\section{Judges as Platonic Kings}

A second, related objection to Charters is that their adoption rests on the false belief that judges are for some reason better able than legislators and citizens to deal responsibly and effectively with the deeply controversial, complex issues of morality and public policy which arise under a Charter. But there is absolutely no reason to accept this belief, the Critics argue. Judges are no better than any one else at determining the content of the fixed points of moral pre-commitment a Charter supposedly represents. Though well schooled in the law, judges are in no sense of the word, moral authorities. Nor are they experts in the various fields of social policy with which government action typically deals. They most certainly do not exhibit degrees of acumen superior to the levels enjoyed by the government authorities whose actions they are called on to sit in moral judgment. So why should they be called upon to decide the deep and difficult questions of political morality which Charter cases involve?

\section{The Threat of Radical Dissensus: Ulysses and the Mast}

In explaining the nature and appeal of Charters, Advocates often cite an analogy with Ulysses' decision to be bound to the mast of his ship. Much as Ulysses knows that he will become mad when he hears the Sirens, we know that at some point we will become overwhelmed by the siren call of self interest, prejudice, fear, hatred or simple moral blindness, and be led, in the course of everyday politics, to violate the rights of vulnerable fellow citizens. And 
just as Ulysses knows that he is rationally justified in arranging, in advance, a restriction on his freedom to choose and act later, we, as a people, know that we are rationally justified in tying ourselves to the mast of entrenched Charter rights and their enforcement, on our behalf, by judges. According to Jeremy Waldron, the radical dissensus found within the circumstances of politics undermines this analogy entirely. Even if there are right answers to questions about moral rights, we almost never agree on what these are. It is therefore sheer folly to believe that we could ever agree on what a Charter's provisions mean and on the moral limits they supposedly impose. Yet if we cannot agree on the relevant limits, we can hardly pre-commit to them and to their enforcement by judges.

\section{Obsession with Words}

Yet another of Waldron's objections to written charters is that the words chosen to describe the appropriate moral limits to government power (e.g. freedom of speech versus freedom of expression) inevitably constrain moral debates about rights artificially by limiting our ability to respond to changing views and circumstances. ${ }^{5}$ Such responses are much easier if instead we allow our evolving understandings of moral rights to be reflected in more flexible and less verbally constrained common law principles and precedents, "and easier still if rights take the form of "conventional understandings" subscribed to the political community at large, as they have in Britain for many years". In pursuing some such alternative strategy, we create the possibility of a public discourse less constrained by verbal formulas and semantic obsessions and better able to pose the questions of moral substance that should really be our principal focus. What we need, Waldron writes, are institutional mechanisms for protecting rights which are "free

5 And because of this they also threaten the ideals of democracy by artificially constraining "the people now" by entrenching decisions taken by "the people then". 
from the obsessive verbalism of a particular written charter". 6 What we need, in other words, is to forget about relying on Charters to establish the appropriate limits to government power.

\section{The Living Tree and the Common Law Conception}

These are just a few of the more prevalent arguments against Charters and the Advocates' standard arguments for them. In each instance there are responses to be made, some of which already exist in the considerable literature spawned by Waldron's critique. ${ }^{7}$ But instead of pursuing these further, I would like to focus on the shared assumption identified at the outset. Consider again the various objections just sketched. In each case the criticism is premised on the critical assumption that Charters aspire to embody fixed points of agreement and pre-commitment which serve to limit government power. With this unstated assumption in place, the Critic goes on to argue that Charters so conceived either fail to live up to this aspiration in the circumstances of politics, or are unworthy of our allegiance in a democratic society. The supposed fact of radical dissensus underlies the first conclusion, that Charters simply cannot do the work their Advocates propose. If we persist in the belief that somehow Charters really can embody the illusive fixed points presupposed, then we will be led to serious worries over their democratic pedigree, and over the insulting admission we seem to be making - that we are better off leaving many of our most fundamental decisions of political morality to a few unelected judges

So if we accept the shared assumption, we have more than enough reason to reject Charters. Yet I cannot help

6 Law and Disagreement, cit., nota 3, 221.

7 See, for example, Christiano, Thomas, "Waldron on Law and Disagreent", Law and Philosophy, 19, 2000, 513-543; Estlund, David, "Jeremy Waldron on "Law and Disagreement»", Philosophical Studies, 99:1, 2000, 111-128; and Kavanagh, Aileen, "Participation and Judicial Review: A Reply to Waldron", Law and Philosophy, 22, 2003, 451-486. 
but wonder whether this amounts to throwing the baby out with the bath water. Whether it does will depend, I submit, on at least two factors: (a) whether we buy into the shared assumption; and (b) whether the particular Charter we choose, and the particular practices of interpretation we adopt for its application, are designed so as to reflect that assumption. In what follows I hope to show that there is little reason to do either of these two things. My argument takes its lead from Hart's penetrating analysis in The Concept of Law of the costs and benefits associated with the rule of law - an analysis to which I would now like to turn.

According to Hart, we face two competing needs whenever we contemplate legal forms of social regulation. On the one hand, there is the need for general rules which can be easily identified in advance, and readily applied without fresh judgment or weighing up of background considerations. On the other hand, there is a distinct need to leave room, at point of application, for further appeal to at least some of those factors. This is largely because unforeseen situations inevitably arise, and these bring into relief issues and questions which cannot possibly be appreciated and intelligently settled in advance. Familiar factors like ignorance of fact, indeterminacy of aim, evolving technologies, changing social contexts and so on, combine to create the ever present possibility that well designed general rules will lead, upon application in specific cases, to absurd or otherwise undesirable results. The pursuit of rules so tightly crafted that they leave, at point of application, no room for informed judgment and discretion, almost always represents a thoroughly unworthy ideal. Fortunately, we have ways of avoiding the pitfalls of this kind of legal formalism. For example, the open texture of natural language permits some measure of the desired leeway. Sometimes this wiggle room arises by accident, as when a hard case just happens to fall within Hart's "penumbra of uncertainty" and this fact can be seized upon to decide on the merits of the case without (undue) concern over the letter of the law. But perhaps 
more importantly, open texture can also be put to use deliberately and in advance, in a wide range of rule-making scenarios. Sometimes we can foresee that cases are very likely to arise in which blind pre-commitment to a particular legal result would have been foolish or for some reason morally problematic. We can know this general fact, even though we cannot foresee the particular unwanted results that are bound to arise. ${ }^{8}$ In this kind of situation, legislators are sometimes wise deliberately to frame open-textured rules incorporating terms like "reasonable", "fair", "due consideration" and so on. Such rules provide some measure of antecedent guidance while allowing both citizen and judge, later called upon to apply the norm, to exercise judgment in avoiding the patently undesirable results to which a more closelytextured rule might have led. Think, for example, of Anglo-American tort law, where the concept of "reasonableness" plays a central role. Here Hart's lessons have been well understood, if not always fully appreciated. Yet these same lessons seem, for the most part, to have been ignored in debates between Charter Critics and Advocates. I want to rectify this theoretical deficit by feeding Hart's insights into the mix. What results, I submit, is a radically different theory about the role a Charter can play for us, one which is far from being undermined by the circumstances of politics. On the contrary, Charters - or at least some Charterscan be seen as a quite sensible response to them.

My alternative theory takes its inspiration not only from Hart, but from an idea articulated long ago by Lord Sankey in Edwards, ${ }^{9}$ a landmark Canadian constitutional case, decided by the Privy Council in 1930, and now commonly referred to as "The Persons Case". Edwards is famous for two reasons: (1) it established that women are indeed "persons" for purposes of appointment to the Canadian Senate; and

8 Think of scenarios involving the use of rapidly changing technologies like the internet. Or scenarios in which significant, individuating factors are likely to be present in most every case arising under a rule, e.g. situations involving the use of force in warding off perceived threats to person and property.

9 Edwards v. A.-G. Canada [1930] A.C. 124. 
(2) it introduced into Canadian constitutional law the "living tree" metaphor, an idea repeatedly endorsed by Canadian courts, and which arguably lies behind key features of Canada's relatively new constitution and the approach Canadian courts have taken to its interpretation and development. 10 Of particular relevance is Section 1 which authorizes reasonable limitations on Charter rights so long as these are prescribed by law and can be "demonstrably justified in a free and democratic society." What is taken to be demonstrably justified is viewed, by Canadian courts, as dependent on an ever-changing social, political and legal context - that is, on a context which more closely resembles a living tree than a frozen landscape. On this conception, constitutionally entrenched Charters in no way aspire to set stable points of agreement and pre-commitment. On the contrary, a Charter is, as the Privy Council said in Edwards, "a living tree capable of growth and expansion within its natural limits". 11 Recall now Waldron's claim that with written Charters we lose "our ability to evolve a free and flexible discourse of politics". The living tree conception seeks to avoid this loss by combining stability with adaptability. We have a written document which enshrines important constitutional rights, but not in a way which fixes them for good. Rather, the relevant moral rights are allowed to develop as contexts change and as various cases of their application arise and are publicly discussed, debated, and ultimately adjudicated in constitutional cases. If this living tree option truly is viable - and it does seem to be the option pursued for some time now in Canada- then our choice is not simply between enacting a Charter and rejecting one altogether. We can also choose the type of Charter

10 See, e.g., A.-G. Que. V. Blaikie [1979] 2S.C.R. 1016, 1029 (language rights); A.-G. B.C. v. Canada Trust Co. [1980] 2 S.C.R. 466, 478 (powers of taxation); Law Society of Upper Canada v. Shapinker [1984] 1 S.C.R. 357, 365 (mobility rights). The idea of the constitution as a "living tree" is, of course, not unique to Canada. Elsewhere the idea is expressed in theories which simply speak of a constitution as a "living thing" or as capable of "organic growth".

11 Edwards, op. cit., note 9, 136. 
we wish to adopt and the approach we wish to take to its interpretation and implementation. Furthermore, in choosing a living tree conception, we can reap many of the benefits for which Charters are celebrated, while avoiding the potential drawbacks to which the Critics rightfully draw our attention.

So treating Charters as "living trees" provides a kind of flexibility at point of application that allows us to accommodate the second of Hart's two fundamental needs. But what about Hart's first need, for norms which can safely be applied without further appeal to background considerations? How can a living tree Charter be made consistent with this fundamental requirement of the rule of law? For a plausible answer we need look no further than the common law - a system of legal regulation which seems capable of satisfying both of Hart's requirements. Despite its well-known adaptability, it is important not to underestimate the ability of the common law to cater to the need for stability and antecedent guidance. Hart again: "Notwithstanding [the ability of courts to distinguish or overrule precedents] the result of the English system of precedent has been to produce, by its use, a body of rules of which a vast number, of both major and minor importance, are as determinate as any statutory rule". ${ }^{12}$ The degree of fixity Hart ascribes to English common law has been challenged.13 And even if Hart's characterization is correct, it remains true that a common law system can pursue adaptability to a far greater extent than Hart describes. But whatever blend of fixity and adaptability a system embodies, the point remains that the common law has a long established history of successfully combining these two properties. If so, then we have reason to look to the common law as a model for understanding the roles that Charters are capable of playing in limiting government

12 The Concept of Law, 2a. ed., Oxford, Clarendon Press, 135.

13 See Simpson, A.W.B., "The Common Law and Legal Theory", Simpson, A. W. B. (ed)., Oxford Essays in Jurisprudence, 2a. series, Oxford: Clarendon Press, 1073. 
power. And if we do so, we also have a way of thinking about Charters which allows us to avoid many of the Critics most powerful objections. Why not view a Charter as setting the stage for a kind of common-law jurisprudence of the moral rights it enshrines? ${ }^{14}$ Why not view a Charter as, in effect, public acknowledgement of the following important points: Sometimes acts of government - lets focus here on acts of legislation - will turn out unforeseeably to infringe one or more key rights of political morality. We cannot always tell, in advance, precisely when this will occur, for the kinds of reasons described by Hart, and for the equally important reason that we seldom, if ever, fully understand the full nature, scope and concrete implications of moral rights. We know that acts of government will sometimes violate important moral rights in unforeseen cases, but we cannot tell, in advance, exactly when and how this is going to occur. Charters, I want to suggest, represent both public recognition of these facts and a promise to address these moral questions when later they appear to arise in concrete cases. They do not fully provide, in advance, the answers we seek, but they do constitute a promise to ask the right questions at the right times - that is, when it is reasonable to believe that key moral rights have been threatened by government action. I'd like now to turn to some of the advantages of viewing Charters this way, and finish with some thoughts on how it allows us to address the Critics' concerns.

\section{Some of the Advantages}

As I noted at the outset, Charters are often said to protect minorities against various majoritarian forces at play in

14 Lack of space precludes a full investigation of this question, but It would appear as though Charter adjudication in the United States and Canada are, in fact, modeled on the common law. As Schauer notes in a review essay, "I sneak in a constitutional example only to remind the reader that American constitutional adjudication in the Supreme Court seems a central case of common law methodology" (Schauer, "Is the Common Law Law?" review of Melvin Eisenberg, The Nature of the Common Law, Cambridge, Harvard University Press, 1988, in 77 Cal. L. Rev. 455). 
democratic politics. They are thought to embody the "rational pre-commitment" of a community to work against these forces by tying itself - and its descendents - to the mast of fundamental rights which limit the valid exercise of government power in service to powerful majorities. We have acknowledged that there are serious problems with this picture, and so it needs to be modified. But there is no reason to think that its essential details cannot remain. For instance, consider again the popular claim that Charter pre-commitment allows the "dead hand of the past" to determine our choices today, thus undermining the very notion of ongoing self-government. A modicum of truth remains in this point since Charters do entrench prior decisions about which rights of political morality deserve constitutional protection as appropriate limits on government power. And even if common law reasoning is brought to bear on how, for purposes of constitutional practice, these rights are to be understood and applied against exercises of government power in concrete cases, the force of precedent will always have to be reckoned with. The dead hand of precedent can be as constraining as the hand of long-dead constitutional authors. But a number of countervailing considerations are worth bearing in mind. First, there is the ever present possibility of constitutional amendment, difficult as it might be to marshal the political will and consensus required to exercise this power. Second, though there is often deep disagreement about the content of the rights enshrined in a Charter, there is seldom serious disagreement, even across generations, over the legitimacy of the rights actually chosen for inclusion. Virtually everyone in contemporary democratic societies agrees that rights to "equality", "freedom of expression" "due process" "freedom of religious belief"15 or "fundamental justice" were worthy of inclusion in the various Charters we find in the world today. A reasonable person might wish, if it were possible to start with a clean slate, for a slightly different collection of rights than those historically settled upon in

15 See Constitution of Mexico, article 30. 
his community, but very few people would deny the legitimacy of the choice actually made. ${ }^{16}$ Third, there is no reason why a Charter might not be designed so as to mitigate the force of the entrenched decisions. Think again of Canada's Section 1 reasonable limitations clause, or of the deferential attitude towards Parliamentary decisions which Canadian courts often display in applying it. Better yet, think of Section 33, which authorizes Parliament and the provincial legislatures to enact legislation which it acknowledges conflicts with a Charter right - or perhaps more accurately, a court's interpretation of a Charter right. Section 33 permits the people now, through its elected legislators, to avoid, for a period of time, and subject to renewal every five years, a court's interpretation of its prior Charter commitments. Fourth, though precedent is always to some degree constraining on future decision makers, the usual common law powers of avoidance are always available to judges in constitutional cases. These powers come in an assortment of forms and with a variety of conditions under which they can be exercised. But under no sensible theory of common law reasoning would a contemporary Supreme Court be completely barred from overruling a constitutional precedent which was confidently believed to have outlived its usefulness or its moral merit. As an example, take the recent Labaye ${ }^{17}$ case which dealt with the Charter rights of a Montreal "swingers club." In its landmark ruling, the Canadian Supreme Court rejected its decades-long commitment to the so-called "community standards of tolerance" test for obscenity and indecency, and put in its place a new test based solely on Mill's harm principle. As Labaye shows, even Supreme Courts are not averse to overruling their own precedents. In light of all these consideration, I think we are safe in concluding that if the dead hand of the past constrains us when we adopt a

16 For instance, some in Canada believe that the "right to property" should have been included in the Canadian Charter. Few, if any, believe, that the Charter is, for this reason, illegitimate.

17 R. v. Labaye 2005 SCC 80. 
Charter, it need not do so in a way which threatens our autonomy as a self governing people.

Fair enough, Charters can be flexible. But we still haven't evaded the force of Waldron's question: why opt for an entrenched, written Charter instead of allowing public discourse, legislative debate, and judicial decisions, all "free from the obsessive verbalism of a particular written charter", to serve as our vehicle for rights protection? 18 If flexibility is so important, then why not go for the most flexible option and reject Charters entirely? The main reason is that Waldron's option really isn't any more flexible - or at least it need not be so. True, with Charters we are constrained to frame our debates in the abstract terms chosen to express its commitments. Americans, for example, have had to discuss expressive freedom in terms of "speech" not "expression." And this has on occasion proved somewhat awkward. But these drawbacks can be mitigated in the various ways canvassed above, e.g., by adopting a common law approach to Charter adjudication or including provisions like Sections 1 and 33 of the Canadian Charter. But even if no such choices have been made, and the Charter chosen is more absolutist in its orientation, there are always ways to achieve the desired level of flexibility. American Courts seem to have managed, in their own ways, to come to much the same judgments about freedom of speech as they would have under a Bill of Rights which employed the broader term "expression" instead. Only those obsessed with the idea that Charters must embody fixed points, established in some way by the plain, literal meaning of words like "speech" and "no law" would reject the idea that it's the moral values behind the linguistic expressions chosen that are of paramount importance. In this instance, these are the individual and political values that argue for the need to recognize a broad, though not unlimited, range of expressive freedoms, of which freedom of oral and written speech is only a species. In short, the words constrain, but not

18 Law and Disagreement, cit., nota 3, 221. 
necessarily to the point where the underlying rights and values are ignored or sacrificed. And if, at some point, the linguistic constraints become too limiting, there is always the option of constitutional amendment.

So Charters need not be hampered by the need "to scramble around constructing...principles out of scraps of some sacred text, in a tendentious exercise of constitutional calligraphy. ${ }^{19}$ But once again, we might reasonably ask: why run even the slightest risk of this kind of unsatisfactory constitutional practice? Why not just abandon written Charters altogether and leave it to the courts and legislatures to develop a flexible jurisprudence of rights in their decisions? One important reason is that, notwithstanding the dangers of allowing words to constrain us in undesirable ways, Hart was right when he insisted that we almost always need to combine the desired flexibility with some measure of stability. And with Charters, interpreted as the living tree model suggests, we seem able to achieve an acceptable blend. Charters are, after all, formally entrenched constitutional documents which solidify the commitments they represent in ways not always possible with less formal means. They also tend, on the whole, to be very well known both by the general population and by the government officials whose powers they serve to limit. Average Canadians, for example, might not know many of the intricate details of how their Charter rights are being dealt with by their courts, but they often know some of this legal history, and they are certainly aware of the Charter's more prominent sections, e.g. Sections 5 (equality) and 33 (the "override" provision). Unwritten rules used to decide cases are, on the other hand, and again for the most part, not nearly so well known. They also tend to be more difficult to state and grasp, and more prone to controversy as to content. For these reasons, they can often be more easily avoided and finessed by government officials. 
So there can be a kind of fixity and stability in written Charters that is not always present with unwritten rules. Though there is much truth in this observation, it would be wrong to overstate it. Well established unwritten rules and conventions, particularly those with constitutional status, can sometimes be as stable as written rules, if only because their elimination, alteration or re-interpretation typically requires widespread changes in traditional attitudes, beliefs and behaviour on the part of a wide range of political actors. And such changes can be as difficult to bring about as a formal constitutional amendment. They can also, given the right set of circumstances, be just as well known as any written rule. So if the case for Charters rests entirely on the potential for a desirable degree of public recognition and stability, we might agree with Waldron that we are better off without one.

Fortunately, there are other consideration in play. A second important reason for a written Charter is its symbolic value. Charters help define and reinforce the character of a community as one publicly committed, in its legal and moral practices, to the fundamental rights and values it includes. These public commitments can, of course, be expressed in other ways, but Charters, as entrenched, foundational documents widely known, cited and understood as embodying the nation's fundamental commitments to its constituent members, are a far more powerful means of expressing those commitments than most any other institutional or conventional vehicle. Ask an American for one feature of the American political culture of which she is most proud, and the answer will likely be the Bill of Rights. Ask a Canadian this same question and the answer is likely to be the Canadian Charter. The latter is seen, not only as embodying Canada's commitment to rights protection, it is seen as expressing, in its commitments to things like multi-culturalism, group rights, equality before and under the law, and the mediating effect of Sections 1 and 33 limi- 
tations, an identity which distinguishes Canada, as a nation, from many of its democratic counterparts.

I can well imagine a Critic replying at this point by acknowledging that a Charter can indeed serve as the inspirational, symbolic instrument just described. I can even imagine him adding that a Charter can usefully serve as the moral and conceptual framework within which public policy debates can take place both inside and outside legislative assemblies. ${ }^{20}$ But I suspect that he would continue to insist that nothing has yet been said to support the further conclusion that we should ask judges to enforce our Charter commitments by developing a common law jurisprudence of them. In other words, even if we agree to adopt a Charter conceived as a living tree, we still have no reason to support the practice of judicial review. Why should we suppose that Charter questions about the appropriate limits to government power are better answered by a few weathered heads in chambers than by some other body like Parliament or Congress, whose responsibility it is in some jurisdictions, e.g. New Zealand, to determine and observe their own Charter limits? Here are some reasons, some of them familiar, for thinking that we might indeed be well served by the judges.

We must begin by acknowledging that there is no reason, in principle, why judges must be assigned the task of interpreting and enforcing the abstract moral provisions of a Charter. As noted, it is certainly possible to require that a legislature observe its own Charter limits - though for fairly obvious reasons, this seems a bit like putting the fox in charge of the hen house. Another possibility is to require, in any hard case in which government action is reasonably

20 Of course the symbolism can prove hollow if the political, legal and social cultures of the society in question fail to reflect the norms formally expressed in their Charter. And there is nothing to rule out the possibility of a society without a Charter possessing a strong culture of respecting the rights typically included in written Charters. The former Soviet Union is often cited as an example of the former, the UK an example of the latter. The only claim I make here, is that within the context of a culture of rights recognition, the powerful symbolism of a Charter can serve an important role. 
judged by a court to infringe a Charter right, that the case be referred back to the enacting body for authoritative settlement. There is obviously very good reason, however, why no contemporary system (of which I am aware) actually pursues this particular model in dealing generally with hard cases. Such cases are so numerous, and complex in their particularity, that an already over-loaded legislature would be swamped were it to assume the responsibility to decide them all. This is among the reasons why we opt for a division of labour and normally assign the task of deciding hard cases to judges. ${ }^{21}$ But if this is true generally, then why should we make an exception when the hard case involves an unforeseen potential violation of a constitutional right?

One reason might be the heightened significance of a typical Charter case - what is at stake, after all, are constitutional rights and values of great significance, and more often than not, deep political and moral disagreement. Surely legislatures can find the time to deal with this limited range of cases. I'm not so sure, however. The number of cases in which, for example, the Canadian Charter figures is enormous. These include, not only all those landmark decisions which make the headlines and generate all the controversy. They also include, in far greater numbers, all those cases in which judges, carefully and deliberately, and without much fanfare, interpret, develop and apply the Charter in deciding the many cases in which the Charter is relevant. Were all such cases returned to the legislature for decision, I suspect that the wheels of government truly would grind to a screeching halt.

Yet another relevant consideration is the possibility that judges are better situated than legislators to decide the

21 Of relevance here is the fact that legislatures, for similar reasons, frequently create and empower (the unelected) members of administrative bodies to enact, interpret and apply specific rules on their behalf. One can easily conceive judges as serving an analogous role. Indeed, this is the role theorists often have in mind when they refer to judicial discretion as representing a kind of "quasi-legislative" power. 
kinds of moral issues which typically arise in Charter cases. Were their contexts of decision-making identical, we might agree with Critics that there is no reason to prefer the decisions of a few unelected people to those of a much larger group of elected people commanding far greater resources, and better able to represent, in their joint deliberations, the full range of reasonable views bearing on the questions at hand. But are the decisional contexts identical? I'm not so sure. Even a Critic must acknowledge the powerful political forces working against responsible, fair-minded decision-making by legislators - factors like political pressure to heed the demands of a self-interested majority bent on ignoring or even suppressing the legitimate interests of a vulnerable minority, or the pressure to bow to the demands of a Prime Minister wielding the immense power of party discipline. These are forces to which judges are largely immune, thanks to the doctrine of judicial independence. So there are familiar strategic reasons for thinking that decisions about whether an act of government has unforeseeably infringed a Charter right might sometimes be better left to judges.

But it would be a mistake, I think, to ignore the following equally important points. For reasons of practical necessity, legislatures almost always rely on the blunt instrument of general legislation, that is, legislation utilizing terms which designate general classes of persons, general features of generally recurring situations, and so on. If so, then whatever solution a legislature proposes to solve a hard case involving the alleged impact of its legislation on a Charter right is likely to meet with the very same fate as the original legislation. That is, it is likely to find its way back to the legislature where a still further attempt to map out, in canonical general terms, a solution to a further hard case will have to be made. It is not easy to imagine intelligible, general legislation which could somehow sensibly cover the variety of different kinds of hard case which have been decided under, say, the equality provisions of the Canadian 
Charter. ${ }^{22}$ One celebrated virtue of the common law is its ability, owing to its inherent adaptability and facility for incremental change through case by case reasoning, to escape these often troublesome features of general statutory regimes. Chief Justice Maclachlin alluded to this feature in Labaye when she remarked that:

Developing, a workable theory of harm [in applying the new harm-based test of obscenity and indecency] is not a task for a single case. In the tradition of the common law, its full articulation will come only as judges consider diverse situations and render decisions on them. Moreover, the difficulty of the task should not be underestimated. We must proceed incrementally, step by cautious step. ${ }^{23}$

As the Chief Justice notes, precedents do not represent attempts to settle issues once and for all by way of fixed general rules. On the contrary, a precedent is typically said to stand only for the actual decision made on the issue(s) raised, and is recognized as provisional and revisable in light of developing case law and the many new situations brought to our attention. Through such incremental, piece by piece changes, what often emerges, over time, is a body of law which exemplifies a level of practical rationality which statutory regimes struggle to achieve. This, the life blood of the common law, is something which the common law conception of Charters both allows and celebrates at the level of constitutional practice.

It may also, I hazard to suggest, be something which judges are better trained than legislators to exemplify. Ronald Dworkin certainly thinks so. In his view,

22 See, for instance, Reaume, Denis, "Of Pigeonholes and Principles: A Reconsideration of Discrimination Law", 40, Osgoode Hall L.J., 2002, 113-144, where Reaume shows the utter mess into which Canadian attempts to implement a statutory regime for discrimination law have fallen. According to Reaume, a far better strategy would have been to allow the courts to develop a common law of discrimination much as it has developed a common law of negligence.

23 Labaye, par. 26. 
...questions of speculative consistency - [that is] questions that test a theory of rights by imagining circumstances in which that theory would produce unacceptable results - are likely to be of importance in an argument about particular rights, because no claim of right is sound if it cannot stand the test of hypothetical counter-example. But the technique of examining a claim of right for speculative consistency is [Dworkin suggests] a technique far more developed in judges than in legislators or in the bulk of the citizens who elect legislators. ${ }^{24}$

It would be foolish to push these last points too far without a good deal more argument - some of which I attempt to provide in my book A Common Law Theory of Judicial Review: The Living Tree. ${ }^{25}$ But perhaps I have said enough to warrant one final, tentative conclusion: There is significant promise in the idea that a Charter both can and should be designed and understood as the common law model suggests, as a set of modest, reasonable commitments developed and applied over time in a case-by-case manner by judges in partnership with other government bodies. In stating this conclusion, I want to stress the idea of partnership. Far too often judges who decide Charter cases are criticized for claiming superior moral insight and authority over legislatures. But as we can now see, this need not be so. The role of legislating general rules whose potential moral consequences cannot always be foreseen or fully appreciated in advance, and in the abstract, is fully compatible with the role, invested in another body, of deciding what must be done when those potential moral consequences are brought to our attention in particular cases. Seen in this light, judges and legislators need not be seen as in competition with each other over who has the better moral vision. On the contrary, they can - and I think should- be viewed

24 Dworkin, A Matter of Principle, Cambridge, Harvard University Press, 1985, 30, emphasis added.

25 Waluchow, W. J., A Common Law Theory of Judicial Review: The Living Tree (forthcoming), Cambridge, Cambridge University Press, 2006. 
as contributing, in their own distinctive ways, to the achievement of a morally enlightened rule of law. If we decline to view our Charters as foolish attempts to establish, in advance and in the dark (as Hart might have put it) an array of fixed constraints on acts of government, and see them instead as living trees whose roots are fixed by precedent and the terms chosen to express the Charter's moral commitments, but whose branches can be allowed to grow over time through the case-by-case development of a common law jurisprudence of moral rights, we stand a better chance of satisfying both of Hart's two fundamental needs, and of reconciling Charters with our self image as self-governing, autonomous rights bearers who, unfortunately, do not have all the answers. ${ }^{26}$

26 Earlier versions of this paper were delivered at McMaster University, The University of Windsor, SUNY Buffalo, and at the Congreso Internacional de Filosofia del Derecho, Mexico, UNAM, Instituto de Investigaciones Jurídicas, March, 2006. I wish to thank all who participated on those occasions for their very helpful advice and criticisms 